\title{
EFFECT OF THE MODE AND DYNAMICS OF THERMAL PROCESSES ON DSC-ACQUIRED PHASE-CHANGE TEMPERATURE AND LATENT HEAT OF DIFFERENT KINDS OF PCM
}

\author{
UGOTAVLJANJE VPLIVOV VRSTE IN DINAMIKE TERMIČNIH \\ PROCESOV NA RAZLIČNE PCM-MATERIALE S POMOČJO \\ DIFERENCIALNE VRSTIČNE KALORIMETRIJE (DSC)
}

\author{
Jan Fořt' ${ }^{1}$ Zbyšek Pavlík ${ }^{1}$, Anton Trník ${ }^{1,2}$, Milena Pavlíková1, Robert Černý1 \\ ${ }^{1}$ Czech Technical University Prague, Faculty of Civil Engineering, Department of Materials Engineering and Chemistry, Thákurova 7 , \\ 16629 Prague 6, Czech Republic \\ ${ }^{2}$ Constantine the Philosopher University in Nitra, Department of Physics, Faculty of Natural Sciences, A. Hlinku 1,94974 Nitra, Slovakia \\ pavlikz@fsv.cvut.cz
}

Prejem rokopisa - received: 2017-02-27; sprejem za objavo - accepted for publication: 2017-05-12

doi: $10.17222 /$ mit. 2017.026

Thermal-energy-storage systems utilizing phase-change materials (PCMs) can find use in many fields, such as solar-energy storage, waste-heat recovery or smart air conditioning in buildings. However, their incorporation into certain building elements and possible utilization of thermal energy are related to the proper understanding of phase-change processes. In this paper, thermophysical properties of five different PCMs were characterised in order to find suitable materials for incorporation into lightweight plasters capable of moderating the interior microclimate of buildings. A DSC analysis as the main investigation method was applied in the range of $-10{ }^{\circ} \mathrm{C}$ to $55^{\circ} \mathrm{C}$, with the heating/cooling rates of $(1,5,10$ and 20$){ }^{\circ} \mathrm{C} / \mathrm{min}$. Based on the DSC data, the temperatures and enthalpies of the phase change were determined as functions of both the modes and dynamics of the simulated thermal process. The obtained results were discussed and proper PCM candidates for an application in lightweight interior plasters were identified.

Keywords: phase-change materials, differential scanning calorimetry, phase-change temperature

Sistemi za skladiščenje toplotne energije, ki izkoriščajo fazne spremembe v materialih (angl. PCMs; Phase Change Materials), se uporabljajo na mnogih področjih, kot na primer pri pridobivanju in skladiščenju sončne energije, izkoriščanju odpadne toplote, ali v inteligentnih prezračevalnih sistemih stavb. Kakorkoli, njihova vgradnja v določene gradbene elemente in možno izkoriščanje odpadne toplote, je povezana $\mathrm{z}$ ustreznim razumevanjem faznih sprememb. $\mathrm{V}$ tem prispevku so bile določene termo-fizikalne lastnosti petih različnih PC materialov, da bi našli ustrezne materiale za vključitev v lahke omete, ki bi bili sposobni uravnavati notranjo mikroklimo stavb. Kot glavna preiskovalna metoda je bila uporabljena DSC (diferencialna vrstična kalorimetrija) analiza v temperaturnem območju med $-10{ }^{\circ} \mathrm{C}$ in $55{ }^{\circ} \mathrm{C}$, s hitrostjo ogrevanja/hlajenja $(1,5,10 \mathrm{in} 20){ }^{\circ} \mathrm{C} / \mathrm{min}$. Glede na podatke DSC-analize, so bile določene temperature in entalpije faznih sprememb v odvisnosti od obeh načinov in dinamike simuliranega termičnega procesa. Dobljeni rezultati so bili preštudirani in najdeni so bili ustrezni PCM-materiali za uporabo v lahkih notranjih ometih.

Ključne besede: materiali s faznimi spremembami, diferenčna dinamična kalorimetrija, temperatura fazne spremembe

\section{INTRODUCTION}

The International Energy Agency noted in its World Energy Outlook ${ }^{1}$ that the building sector is responsible for approx. $30 \%$ of the total energy consumption in the US and Europe, whereas in developing countries, this consumption is even higher, about $41 \%$. A substantial part of energy is consumed by a building's cooling and heating in order to ensure a high living standard of the building occupants. Nowadays, building energy efficiency and a decrease in greenhouse-gas emissions are of particular importance. Techniques known as passive cooling are extensively studied and used in environmentally friendly technologies for moderation of interior climate.

Modern lightweight buildings bring many advantages compared to the standard heavyweight constructions, such as construction speed, economic benefits and architectural flexibility. Nevertheless, lightweight building envelopes are more sensitive to the temperature fluctuation because of their low thermal-storage capacity. ${ }^{2} \mathrm{~A}$ decrease in the thermal-storage capacity leads to a higher need for moderation of interior climate due to the external and/or internal thermal load. Incorporation of PCMs into the lightweight building envelopes can result in a more stable interior temperature with lower requirements on additional heating/cooling equipment. ${ }^{3}$ Latent-heatstorage (LHS) systems can be utilized for the optimization of the ambient temperature, especially during summer and winter temperature peaks or daily and nightly fluctuations. These fluctuations are accompanied by high energy consumption, creating demands on airconditioning systems in order to satisfy the requirements on indoor comfort temperature. ${ }^{4}$ The efficiency of LHS 


\section{J. FOŘT et al.: EFFECT OF THE MODE AND DYNAMICS OF THERMAL PROCESSES ...}

is strongly connected with the parameters of applied PCMs which must comply with thermophysical, chemical and economic requirements.

PCM characteristics provided by manufacturers without any exact information on the measurement methodology can often be misrepresented, inaccurate, or too optimistic, thus they require further study. Reliable parameters of PCMs are essential for the design of building materials and components for latent-heat storage and moderation of the interior climate. For a proper use of PCMs, the temperature dependence of the enthalpy around the phase transition has to be known with a good accuracy. Analysis techniques used to study the phase change are mainly conventional calorimetry, differential scanning calorimetry (DSC) and differential thermal analysis (DTA). However, other methods, e.g., the T-history method proposed by J. M. Marín ${ }^{5}$, also found use in PCM tests. For the measurement of the PCM thermal conductivity, the hot-disk method is often used. ${ }^{6}$ As mentioned by B. Zalba, ${ }^{7}$ there is considerable uncertainty about the property values provided by the manufacturers (who give values of pure substances) and it is therefore advisable to use DSC to obtain more accurate values. In $\mathrm{DSC}$, a reference sample is made to increase (or decrease) its temperature at a constant rate and the PCM sample is forced to follow this rate by changing the power delivered to it. This allows one to extract the heat capacity as a function of temperature. The transition heat is then determined by integrating the heat-capacity curve. The shape of the specific heat-capacity function depends significantly on the heating and cooling rates used in the measurements. Different scanning rates ranging from $0.2 \mathrm{~K} / \mathrm{min}$ to $10 \mathrm{~K} / \mathrm{min}$ were employed in DSC tests to investigate the thermophysical properties of PCMs. ${ }^{8}$ Frequently, the enthalpy function or the apparent heat capacity of a PCM is determined on the basis of DSC measurements made at too high heating/cooling rates. ${ }^{9}$ It was found that the standards used in calorimetry designed for the materials other than PCMs are not suitable for PCM testing due to the high heating rate, affecting the melting/solidification range and stored heat. When DSC runs at a higher scanning rate, it will give design information that may not be sufficiently accurate. In addition, the data on the measurements using different scanning rates are not comparable. ${ }^{10} \mathrm{H}$. Mehling et al. ${ }^{11}$ proposed summarizing the standards for PCM testing, in order to ensure the reproducibility and comparability of PCM products. However, although many studies on the PCM experimental characterization were conducted, no universal methodology for the DSC tests of PCMs have yet been developed. This is partially due to the variety of PCM compositions as they are composed of paraffins, fatty acids, hydrated salts, etc. For example, a characteristic of most paraffins and salt hydrates is that the phase change occurs in the temperature range, rather than at a constant temperature as would be expected for pure substances.
On this account, a detailed testing of five PCMs on a paraffin basis was done in our research to describe the materials' thermal behaviour, taking into account the temperature-change rate and the mode of the thermal process (heating or cooling). The presented experimental work aimed also at a comparison of two different groups of PCMs prepared using microencapsulation and dispersion in water.

\section{EXPERIMENTAL PART}

For the evaluation of the PCM potential for the heat storage in lightweight building elements, five types of commercially produced PCMs were examined. Two of them were polymethyl methacrylate microencapsulated paraffin mixtures produced by BASF. They were in the form of fine powders (a particle size of 50-300 $\mu \mathrm{m}$ ) having the solid content of $97-100 \%$ (according to DIN EN ISO 3251) and water content $\leq 3 \%$. According to the data provided by BASF, the first product, Micronal DS $5038 \mathrm{X}$, has a melting temperature of about $26^{\circ} \mathrm{C}$ and an enthalpy of fusion of $110 \mathrm{~J} / \mathrm{g}$. The second one, Micronal DS $5040 \mathrm{X}$, has a slightly lower melting temperature of $23{ }^{\circ} \mathrm{C}$ and an enthalpy of fusion of 100 $\mathrm{J} / \mathrm{g} .{ }^{12}$ The second group of the materials was produced by Rubitherm. These materials were also based on a paraffin mixture encapsulated in a polymer shell, but they were delivered in the form of water dispersion with the solid content of about $35 \%$. The company product labels of these materials are RT $21 \mathrm{HC}$, RT $22 \mathrm{HC}$ and RT $25 \mathrm{HC}$. They have the main peak of the phase-change temperature at $(21,22$ and 25$){ }^{\circ} \mathrm{C}$, respectively. The heat-storage-capacity values declared by the producer are (190, 200 and 230) J/g. ${ }^{13}$

For the basic characterization of the tested PCMs, measurements of bulk and powder densities were done. The bulk and powder densities were obtained from the measurement of the sample volume and mass. Powdered materials were characterized by the powder density and the PCMs in the form of water dispersion were characterized by their bulk density. The relative expanded uncertainty of these tests was $3.4 \%$.

Thermal conductivity was measured with an Isomet 2114 device (applied precision) which operates on a transient-measurement principle. The measurement range of the thermal conductivity was from $0.015 \mathrm{~W} / \mathrm{mK}$ to $6.0 \mathrm{~W} / \mathrm{mK}$ with the accuracy of $5 \%$ of the reading + $0.001 \mathrm{~W} / \mathrm{mK}$. For the measurement, a needle probe that was inserted into the examined PCMS was used. The expanded combined uncertainty was $4.3 \%$.

A DSC 822e (Mettler Toledo) device was employed in the experiments, together with a Julabo FT 900 cooling device. Temperature and heat-flow calibrations are very important for the accuracy of the data obtained with DSC. ${ }^{14}$ The calibration of the measuring apparatus was done according to ISO $11357-1 .^{15}$ To avoid wasting time while keeping the data accuracy satisfactory, we 
used "smart" temperature programs proposed by A. Shimkin for the calibration. ${ }^{16}$ The samples $(\sim 10 \mathrm{mg}$ for the BASF materials and $\sim 30 \mathrm{mg}$ for the Rubitherm PCMs) were placed into an aluminum crucible with a volume of $40 \mathrm{~mm}^{3}$. During the measurement, the following temperature regimes were applied: $5 \mathrm{~min}$ of the isothermal regime, cooling at $\left(1,5,10\right.$ and 20) ${ }^{\circ} \mathrm{C} / \mathrm{min}$ from $55{ }^{\circ} \mathrm{C}$ to $-10{ }^{\circ} \mathrm{C}, 5 \mathrm{~min}$ of the isothermal regime, heating at $(1,5,10$ and 20$){ }^{\circ} \mathrm{C} / \mathrm{min}$ from $-10{ }^{\circ} \mathrm{C}$ to $55{ }^{\circ} \mathrm{C}, 5 \mathrm{~min}$ of the isothermal regime. All the experiments were done in an air atmosphere with a flow rate of $40 \mathrm{~mL} / \mathrm{min}$. The enthalpy of fusion was obtained by integrating the peak area between the start and end temperatures of the peak. The measurement of the heat capacity was carried out using sapphire as the reference sample. Thus, the procedure for measuring the heat capacity consisted of three identical steps: 1 . measurement of the blank (the empty crucible), 2. measurement of the sapphire, 3. measurement of the studied sample. Then, the heat capacity was calculated with Equation (1):

$$
C_{\mathrm{p}}=C_{\mathrm{pr}} \frac{m_{\mathrm{r}}\left(H_{\mathrm{s}}-H_{\mathrm{b}}\right)}{m_{\mathrm{s}}\left(H_{\mathrm{r}}-H_{\mathrm{b}}\right)}
$$

where $C_{\mathrm{pr}}(\mathrm{J} / \mathrm{gK})$ is the heat capacity of the reference sample (sapphire), $m_{\mathrm{r}}(\mathrm{g})$ is the mass of the reference sample (sapphire), $m_{\mathrm{s}}(\mathrm{g})$ is the mass of the studied sample, and $H_{\mathrm{b}}, H_{\mathrm{r}}$, and $H_{\mathrm{s}}(\mathrm{W} / \mathrm{g})$ are the heat flows of the blank, the reference sample (sapphire) and the studied sample, respectively. The onset and endset temperatures and the enthalpy of fusion were assessed as the average of three independent measurements, while the endset and onset temperatures were identified according to ISO $11357-3: 2011 .^{17}$ According to this
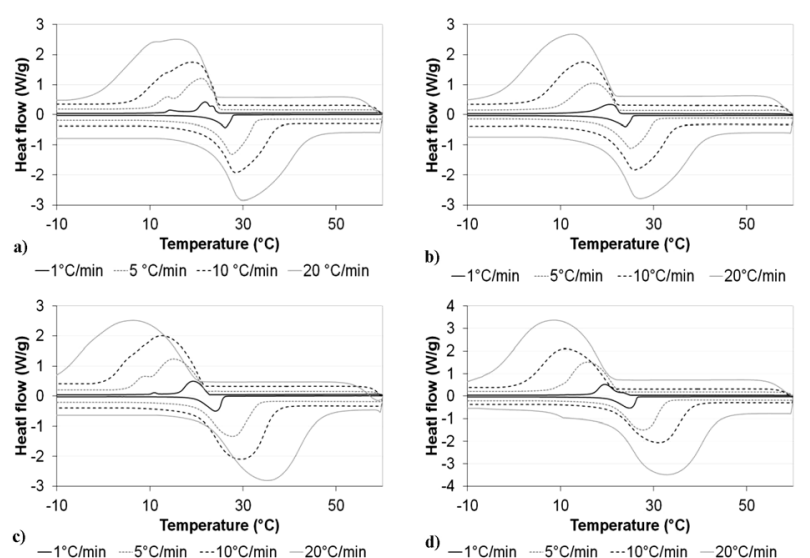

c) $-1^{\circ} \mathrm{C} / \mathrm{min} \quad 5^{\circ} \mathrm{C} / \mathrm{min} \quad-10^{\circ} \mathrm{C} / \mathrm{min} \quad-20^{\circ} \mathrm{C} / \mathrm{min}$

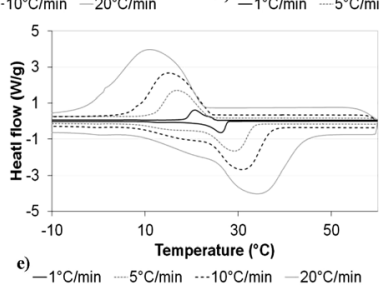

Figure 1: Heat flow during heating and cooling of: a) Micronal DS 5038 X, b) Micronal DS 5040 X, c) Rubitherm RT 21, d) Rubitherm RT 22, e) Rubitherm RT 25
ISO standard, the extrapolated onset temperature is where the extrapolated baseline is intersected by the tangent to the curve at the point of inflection and corresponds to the start of the transition; the extrapolated endset temperature is where the extrapolated baseline is intersected by the tangent to the curve at the point of inflection and corresponds to the end of the transition; the peak temperature is the temperature, at which the peak reaches the maximum (or minimum).

\section{RESULTS AND DISCUSSION}

The basic physical properties of the studied materials are given in Table 1. The data represents the average values from five measurements. The data was obtained in laboratory conditions of $23.0 \pm 2{ }^{\circ} \mathrm{C}$ and $30.0 \pm 2 \% \mathrm{RH}$.

Table 1: Basic physical properties and thermal conductivity of the studied PCMS

\begin{tabular}{|c|c|c|c|}
\hline \multirow{2}{*}{ PCM } & $\begin{array}{c}\text { Powder } \\
\text { density }\end{array}$ & $\begin{array}{c}\text { Bulk } \\
\text { density }\end{array}$ & $\begin{array}{c}\text { Thermal } \\
\text { conductivity }\end{array}$ \\
\cline { 2 - 4 }$\left(\mathrm{kg} / \mathrm{m}^{3}\right)$ & $\left(\mathrm{kg} / \mathrm{m}^{3}\right)$ & $(\mathrm{W} / \mathrm{m} \mathrm{K})$ \\
\hline Micronal DS 5038 X & 361 & - & 0.080 \\
\hline Micronal DS 5040 X & 365 & - & 0.079 \\
\hline Rubitherm RT 21 & - & 787 & 0.442 \\
\hline Rubitherm RT 22 & - & 789 & 0.445 \\
\hline Rubitherm RT 25 & - & 787 & 0.444 \\
\hline
\end{tabular}

The powder densities of both BASF materials were very similar, while the examined Rubitherm materials exhibited almost identical values of the bulk density. For both powdered BASF materials, the thermal conductivity values were very low due to the presence of air gaps between the particles. The assumed incorporation of the PCM into the silicate matrix (cement or cement-lime plasters) with almost no air between the PCM particles is, of course, supposed to result in an increased thermal conductivity as presented, for example, by Z. Wang et al. ${ }^{18}$ On the other hand, the thermal conductivities of the PCM dispersions were much higher. This was due to the presence of more than $60 \%$ of water in the dispersion. From a practical point of view, a high thermal conductivity of PCMs ensures their effective thermal performance, thus the optimum usage of the latent heat.

Figure 1 describes the results of the DSC analysis used for the determination of the phase-change temperature, the enthalpy of phase transition and the specific heat capacity of the examined materials. A significant effect of the heating and cooling rate on the monitored temperature of the phase-change transition was observed in all the cases. Generally, with the increasing heating/ cooling rate, the phase-change-transition range was more spread; this feature was more remarkable for the materials based on dispersion. A similar PCM performance with respect to the heating rate applied in a DSC analysis was observed, e.g., by G. Feng et al. ${ }^{19}$ who analysed capric acid of high purity ( $\geq 99.9 \%$ ) so that the influence of the material impurity on DSC results was 


\section{J. FOŘT et al.: EFFECT OF THE MODE AND DYNAMICS OF THERMAL PROCESSES ...}

neglected. G. Feng et al. ${ }^{19}$ applied heating rates of (10, 5, 1, 0.5 and 0.1$){ }^{\circ} \mathrm{C} / \mathrm{min}$. When the heating/cooling rate increased from $0.1{ }^{\circ} \mathrm{C} / \mathrm{min}$ to $10{ }^{\circ} \mathrm{C} / \mathrm{min}$, the biggest deviations in solid- and liquid-transition temperatures were $1.1^{\circ} \mathrm{C}$ and $6.4{ }^{\circ} \mathrm{C}$, respectively.

In our case, when the heating or cooling rate increased from $1{ }^{\circ} \mathrm{C} / \mathrm{min}$ to $20{ }^{\circ} \mathrm{C} / \mathrm{min}$, the biggest difference in the onset of the liquid-transition temperature was $1.9{ }^{\circ} \mathrm{C}$ (measured for Rubitherm RT 21) and it was $2.8{ }^{\circ} \mathrm{C}$ for the onset of the solidification temperature (for Rubitherm RT 25). On the other hand, sharp boundaries of the phase-change transition were found for the lower rates of the heating. In this case, it was easy to identify the onset and endset temperatures of the phase change and to calculate its corresponding enthalpy.

The onset and endset temperatures used for the assessment of the enthalpy of the phase transition are given in Table 2. Comparing the measured onset and endset temperatures with the phase-change temperatures declared by the producers, the mean values measured for the lower heating/cooling rates corresponded to those provided on PCM product sheets.

Table 2: Phase-change temperatures

\begin{tabular}{|c|c|c|c|c|c|}
\hline \multirow{2}{*}{ PCM } & \multirow{2}{*}{$\begin{array}{l}\text { Temperature- } \\
\text { change rate } \\
\left({ }^{\circ} \mathrm{C} / \mathrm{min}\right)\end{array}$} & \multicolumn{2}{|c|}{ Heating $\left({ }^{\circ} \mathrm{C}\right)$} & \multicolumn{2}{|c|}{ Cooling $\left({ }^{\circ} \mathrm{C}\right)$} \\
\hline & & Onset & Endset & Onset & Endset \\
\hline \multirow{4}{*}{$\begin{array}{l}\text { Micronal } \\
\text { DS } 5038 \mathrm{X}\end{array}$} & 1 & 23.3 & 27.8 & 23.7 & 19.5 \\
\hline & 5 & 23.2 & 32.8 & 24.7 & 14.0 \\
\hline & 10 & 22.9 & 37.4 & 24.6 & 6.2 \\
\hline & 20 & 22.8 & 44.1 & 24.2 & -1.7 \\
\hline \multirow{4}{*}{$\begin{array}{l}\text { Micronal } \\
\text { DS } 5040 \mathrm{X}\end{array}$} & 1 & 19.6 & 25.5 & 22.7 & 15.9 \\
\hline & 5 & 19.5 & 30.4 & 22.4 & 17.0 \\
\hline & 10 & 19.4 & 34.5 & 22.1 & 4.7 \\
\hline & 20 & 19.3 & 41.1 & 21.6 & -3.5 \\
\hline \multirow{4}{*}{$\begin{array}{l}\text { Rubitherm } \\
\text { RT } 21 \mathrm{HC}\end{array}$} & 1 & 19.6 & 25.7 & 22.5 & 16.2 \\
\hline & 5 & 19.9 & 33.2 & 21.9 & 8.4 \\
\hline & 10 & 20.1 & 37.0 & 21.5 & 12.6 \\
\hline & 20 & 21.5 & 46.2 & 19.9 & -10.1 \\
\hline \multirow{4}{*}{$\begin{array}{l}\text { Rubitherm } \\
\text { RT } 22 \text { HC }\end{array}$} & 1 & 20.4 & 26.4 & 22.7 & 16.9 \\
\hline & 5 & 20.7 & 32.5 & 22.3 & 9.9 \\
\hline & 10 & 20.7 & 38.3 & 21.0 & 2.0 \\
\hline & 20 & 21.0 & 43.7 & 20.6 & -4.9 \\
\hline \multirow{4}{*}{$\begin{array}{l}\text { Rubitherm } \\
\text { RT } 25 \mathrm{HC}\end{array}$} & 1 & 22.7 & 27.6 & 24.9 & 18.7 \\
\hline & 5 & 22.0 & 33.1 & 23.5 & 12.0 \\
\hline & 10 & 21.7 & 36.9 & 23.8 & 8.7 \\
\hline & 20 & 21.0 & 44.3 & 22.1 & 1.7 \\
\hline
\end{tabular}

Considering the DSC plots, we can see that during the heating process all the measured heat flux vs. temperature curves exhibited a unimodal character. On the other hand, during the cooling, bimodal or even trimodal shapes were obtained for materials Micronal DS $5038 \mathrm{X}$ and Rubitherm RT 21 HC. In the past, bimodal shapes of DSC curves were found by other investigators as well. J. Jeon et al. ${ }^{20}$ reported on two phase-change peaks of paraffin. The first phase-change peak in the cooling process was high, corresponding to the liquid-solid transition of paraffin, but the second peak was much lower. As it was analysed in detail by N. Ukrainczyk et al. ${ }^{21}$, this smaller endotherm corresponds to the solid-solid transition when the close-packed hexagonal system of paraffin transforms into the orthorhombic or monoclinic (depending on the number of carbon atoms in a molecule) crystalline structure.

Considering the findings of the other investigators mentioned above, the shapes of the DSC plots of Micronal DS $5038 \mathrm{X}$ and Rubitherm RT 21 in the cooling phase can be explained with two main effects. First, the paraffin underwent two phase transitions. ${ }^{20,21}$ Second, due to the high cooling rate adopted for the DSC analysis, the super-cooling phenomena could also contribute to the appearance of the bimodal (or/and trimodal) shape of the DSC plots. ${ }^{22}$

In Table 3, the enthalpies of fusion and crystallization in dependence on the heating and cooling rate are presented. The PCMs produced by BASF exhibited substantially lower enthalpies, as compared to the values obtained for the materials delivered by Rubitherm. While the enthalpy values of the BASF products varied from $93 \mathrm{~J} / \mathrm{g}$ to $103 \mathrm{~J} / \mathrm{g}$, the Rubitherm materials yielded the enthalpy in a range of $113-183 \mathrm{~J} / \mathrm{g}$. Enthalpy values similar to those shown in Table 4 were obtained, e.g., by J. Jeon et al. ${ }^{20}$ and X. Liu at al. ${ }^{23}$ who obtained, for paraffinic waxes, enthalpies of fusion of $144.6 \mathrm{~J} / \mathrm{g}$ and $153.5 \mathrm{~J} / \mathrm{g}$, respectively. Comparing the measured data with the enthalpy values provided on product sheets, the values obtained in our case were lower, especially for the Rubitherm materials.

Table 3: Phase-change enthalpies

\begin{tabular}{|c|c|c|c|}
\hline \multirow{2}{*}{ PCM } & \multirow{2}{*}{$\begin{array}{l}\text { Temperature- } \\
\text { change rate } \\
\left({ }^{\circ} \mathrm{C} / \mathrm{min}\right)\end{array}$} & \multicolumn{2}{|c|}{ Enthalpy (J/g) } \\
\hline & & Heating & Cooling \\
\hline \multirow{4}{*}{$\begin{array}{c}\text { Micronal DS } \\
5038 \mathrm{X}\end{array}$} & 1 & 99.5 & 102.6 \\
\hline & 5 & 101.2 & 103.4 \\
\hline & 10 & 98.9 & 103.6 \\
\hline & 20 & 97.9 & 103.9 \\
\hline \multirow{4}{*}{$\begin{array}{c}\text { Micronal DS } \\
5040 \mathrm{X}\end{array}$} & 1 & 97.7 & 100.3 \\
\hline & 5 & 94.0 & 96.1 \\
\hline & 10 & 95.2 & 98.8 \\
\hline & 20 & 96.0 & 103.2 \\
\hline \multirow{4}{*}{$\begin{array}{c}\text { Rubitherm RT } \\
21 \mathrm{HC}\end{array}$} & 1 & 124.3 & 131.6 \\
\hline & 5 & 125.5 & 128.8 \\
\hline & 10 & 126.9 & 131.3 \\
\hline & 20 & 113.0 & 119.0 \\
\hline \multirow{4}{*}{$\begin{array}{c}\text { Rubitherm RT } \\
22 \mathrm{HC}\end{array}$} & 1 & 134.0 & 128.2 \\
\hline & 5 & 131.9 & 134.2 \\
\hline & 10 & 126.0 & 130.6 \\
\hline & 20 & 125.8 & 131.3 \\
\hline \multirow{4}{*}{$\begin{array}{c}\text { Rubitherm RT } \\
25 \mathrm{HC}\end{array}$} & 1 & 175.0 & 166.8 \\
\hline & 5 & 177.3 & 167.8 \\
\hline & 10 & 178.5 & 171.1 \\
\hline & 20 & 174.9 & 183.2 \\
\hline
\end{tabular}


The heating/cooling-rate change resulted in only small differences between the measured enthalpies of fusion and crystallization $(<7 \%)$ up to $10{ }^{\circ} \mathrm{C} / \mathrm{min}$. For $20{ }^{\circ} \mathrm{C} / \mathrm{min}$, the differences were higher in some cases (Rubitherm RT $21 \mathrm{HC}$ for both the heating and cooling phase, Rubitherm RT $25 \mathrm{HC}$ for the cooling phase) which could be attributed to the higher uncertainty of the measurement of higher temperature-change rates and the difficulty to distinguish the endset and onset temperatures of the phase change. The differences between the enthalpies of fusion and crystallization of particular tested materials were small in all the cases, up to $6 \%$; they were well within the measurement uncertainty.

Figure 2 shows the specific-heat-capacity plots obtained from the DSC tests. The data represents the average values of three measurements. All the tested materials exhibited an increase in the specific-heat capacity during the melting. Similar to the heat-flow plots shown in Figures 1 to 5, a remarkable increase in the specific-heat capacity with the decreasing temperature-change rate was observed in the temperature ranges corresponding to the solid-liquid phase transitions. For instance, for the heating rate of $1{ }^{\circ} \mathrm{C} / \mathrm{min}$, the specificheat-capacity function of Micronal DS 5038 X reached the maximum at $30.1 \mathrm{~J} / \mathrm{g} \mathrm{K}$. When the heating rate of 20 ${ }^{\circ} \mathrm{C} / \mathrm{min}$ was used, the specific-heat-capacity maximum was only $8.5 \mathrm{~J} / \mathrm{g} \mathrm{K}$. This finding can have significant consequences for the practical capabilities of particular PCMs to moderate the interior climate of a building exposed to different exterior climatic loads as well as to moderate technological processes, energy recuperation, etc.
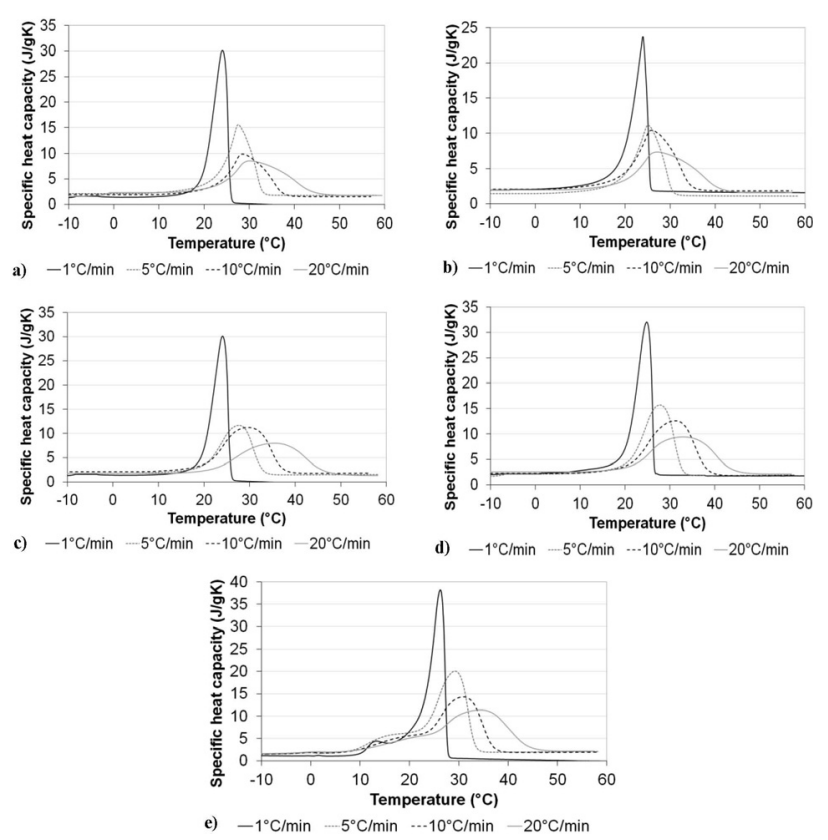

Figure 2: Specific-heat capacity during heating: a) Micronal DS 5038 X, b) Micronal DS 5040 X, c) Rubitherm RT 21, d) Rubitherm RT 22, e) Rubitherm RT 25
From a quantitative point of view, the measured values of the specific-heat capacity corresponding to melting are very high, making the studied PCMs well applicable for effective heat storage in building and construction elements. For lower temperatures, for example $10{ }^{\circ} \mathrm{C}$, the measured specific-heat capacity dropped and reached values of 1.4-2.6 J/g K. Similar results for paraffin $E_{53}$ were reported by E. M. Anghel et al. ${ }^{24}$ who obtained, at $10{ }^{\circ} \mathrm{C}$, a specific heat capacity of $1.6 \mathrm{~J} / \mathrm{g} \mathrm{K}$. Similarly, D. Zhou et al..$^{25}$ reported on the specific-heat capacity of Rubitherm 25 that was $2.1 \mathrm{~J} / \mathrm{g} \mathrm{K}$.

\section{CONCLUSIONS}

A thermophysical analysis of several different PCMs in the form of a fine powder and water dispersion was done, taking into account the effects of the mode and dynamics of a DSC-simulated thermal process on phase-change characteristics.

The main results of the experimental work can be summarized in the following points:

- The choice of a proper heating/cooling mode of the DSC test was of particular importance for the evaluation and generalization of the PCM thermal performance. In this respect, it was found that a universal methodology for testing PCMs with an assumed application in the construction industry is actually missing although the low-temperature change rate looks promising for a detailed description of phase-change processes.

- A significant effect of the heating and cooling rate on the monitored temperature of the phase-change transition was observed for all the studied PCMs. Generally, with the increasing rate of the temperature change, the phase-change-transition range was more spread; this feature was more remarkable for the materials based on dispersion.

- The temperature-rate change resulted in only small differences between the measured enthalpies of fusion and crystallization up to $10{ }^{\circ} \mathrm{C} / \mathrm{min}$.

- The powdered PCMs produced by BASF exhibited substantially lower phase-change enthalpies, when compared to the water-dispersed PCMs delivered by Rubitherm. This was in agreement with the data provided by PCM producers. However, all the studied materials were found to be suitable candidates for application in lightweight interior plasters.

- An increase in the heating rate led to a decrease in the maximum specific-heat capacity in the desired operational range of the examined PCMs. From the point of view of their assumed application for the moderation of a building's interior climate, their effectiveness is better for slower temperature changes, as in common climatic conditions.

- Based on the findings presented above, it can be concluded that from a practical point of view, aiming at an effective use of PCMs in the conditioning of a 


\section{J. FOŘT et al.: EFFECT OF THE MODE AND DYNAMICS OF THERMAL PROCESSES ...}

building's interior climate, the most crucial is the monitoring of temperature fluctuations in the interior and the performance of a DSC analysis according to the measured indoor-temperature-rate change. In this way, the choice of a proper PCM will consider the actual conditions of a building, and the thermal envelope with the incorporated PCM will be "tailormade".

\section{Acknowledgment}

Authors gratefully acknowledge the financial support of the Czech Science Foundation, under project No P105/12/G059.

\section{REFERENCES}

${ }^{1}$ World Energy Outlook 2010, OECD/IEA, SOREGRAPH, Paris Cedex 2010, 731

${ }^{2}$ Y. Zhang, S. Zhuang, Q. Wang, J. He, Experimental research on the thermal performance of composite PCM hollow block walls and validation of phase transition heat transfer models, Adv. Mater. Sci. Eng., (2016), doi:10.1155/2016/6359414

${ }^{3}$ A. G. Entrop, H. J. H. Brouwers, A. H. M. E. Reinders, Experimental research on the use of micro-encapsulated phase change materials to store solar energy in concrete floors and to save energy in Dutch houses, Sol. Energy, 85 (2011), doi:10.1016/j.solener.2011.02.017

${ }^{4}$ F. Agyenim, N. Hewitt, P. Eames, M. Smyth, A review of materials, heat transfer and phase change problem formulation for latent heat thermal storage systems (LHTESS), Renew. Sust. Energ. Rev., 14 (2010), doi:10.1016/j.rser.2009.10.015

${ }^{5}$ J. M. Marín, B. Zalba, L. F. Cabeza, H. Mehling, Determination of enthalpy-temperature curves of phase change materials with the temperature-history method: improvement to temperature dependent properties, Measurement Sci. Technol., 14 (2003), doi:10.1088/ 0957-0233/14/2/305

${ }^{6}$ L. Gao, J. Zhao, Q. An, D. Zhao, F. Meng, X. Liu, Experiments on thermal performance of erythritol/expanded graphite in a direct contact thermal energy storage container, Appl. Therm. Eng., 113 (2017), doi:10.1016/j.applthermaleng.2016.11.073

B. Zalba, J. M. Marín, L. F. Cabeza, H. Mehling, Review on thermal energy storage with phase change: materials, heat transfer analysis and applications, Appl. Therm. Eng., 23 (2003), doi:10.1016/S13594311(02)00192-8

${ }^{8}$ P. Losada-Pérez, C. S. P. Tripathi, J. Leyes, G. Cordoyiannis, C. Glorieux, J. Thoen, Measurement of heat capacity and enthalpy of phase change materials by adiabatic scanning calorimetry, Int. J. Thermophys., 32 (2011), doi:0.1007/s10765-011-0984-0

${ }^{9}$ C. Arkar, S. Medved, Influence of accuracy of thermal property data of a phase change material on the result of a numerical model of a packed bed latent heat storage with spheres, Thermochim. Acta, 438 (2005), doi:10.1016/j.tca.2005.08.032
${ }^{10}$ B. He, V. Martin, F. Setterwall, Phase transition temperature ranges and storage density of paraffin wax phase change materials, Energy, 29 (2004), doi:10.1016/j.energy.2004.03.002

${ }^{11}$ H. Mehling, H. P. Ebert, P. Schossig, Development of standards for materials testing and quality control of PCM, $7^{\text {th }}$ IIR Conference on Phase Change Materials and Slurries for Refrigeration and Air Conditioning, Dinan 2006, 1-9

${ }^{12}$ Product Overview, BASF company, http://product-finder.basf.com, 6.4.2017

${ }^{13}$ PCM RT-Line, Rubitherm, https://www.rubitherm.eu, 6.4.2017

${ }^{14}$ E. Gmelin, S. M. Sarge, Temperature, heat and heat flow rate calibration of differential scanning calorimeters, Thermochim. Acta, 347 (2000), doi:10.1016/S0040-6031(99)00424-4

${ }^{15}$ ISO 11357-1:2016 Plastics - Differential scanning calorimetry (DSC) - Part 1: General principles, ISO Committee, Geneve

${ }^{16}$ A. Shimkin, Optimization of DSC calibration procedure, Thermochim. Acta, 566 (2013), doi:10.1016/j.tca.2013.04.039

${ }^{17}$ ISO 11357-3:2011 Plastics - Differential scanning calorimetry (DSC) - Part 3: Determination of temperature and enthalpy of melting and crystallization, ISO Committee, Geneve

${ }^{18}$ Z. Wang, H. Su, S. Zhao, N. Zhao, Influence of phase change material on mechanical and thermal properties of clay geopolymer mortar, Constr. Build. Mater., 120 (2016), doi:10.1016/j.conbuildmat.2016.05.091

${ }^{19}$ G. Feng, K. Huang, H. Xie, H. Li, X. Liu, S. Liu, DSC test error of phase change material (PCM) and its influence on the simulation of the PCM floor, Renew. Energy, 87 (2016), doi:10.1016/j.renene. 2015.07.085

${ }^{20}$ J. Jeon, S. G. Jeong, J. H. Lee, J. Seo, S. Kim, High thermal performance composite PCMs loading $\mathrm{xGnP}$ for application to building using radiant floor heating system, Sol. Energ. Mater. Sol. C., 101 (2012), doi:10.1016/j.solmat.2012.02.028

${ }^{21}$ N. Ukrainczyk, S. Kurajica, J. Sipusic, Thermophysical comparison of five commercial paraffin waxes as latent heat storage materials, Chem. Biochem. Eng. Q., 24 (2010)

${ }^{22}$ Z. Pavlík, J. Fořt, M. Pavlíková, J. Pokorný, A. Trník, R. Černý, Modified lime-cement plasters with enhanced thermal and hygric storage capacity for moderation of interior climate, Energ. Buildings, 126 (2016), doi:10.1016/j.enbuild.2016.05.004

${ }^{23}$ X. Liu, H. Liu, S. Wang, L. Zhang, H. Cheng, Preparation and thermal properties of form stable paraffin phase change material encapsulation, Energ. Convers. Manage., 47 (2006), doi:10.1016/ j.enconman.2005.10.031

${ }^{24}$ E. M. Anghel, A. Georgiev, S. Petrescu, R. Popov, M. Constantinescu, Thermo-physical characterization of some paraffins used as phase change materials for thermal energy storage, J. Therm. Anal. Calorim., 117 (2014), doi:10.1007/s10973-014-3775-6

${ }^{25}$ D. Zhou, C. Y. Zhao, Y. Tian, Review on thermal energy storage with phase change materials (PCMs) in building applications, Appl. Energ. 92 (2012), doi:10.1016/j.apenergy.2011.08.025 